\title{
Examining the family dynamics in addiction: Inputs for treatment intervention in the Philippine setting
}

\author{
Abulon, Edna Luz $\bowtie$ \\ Philippine Normal University, Philippines (abulon.elv@pnu.edu.ph) \\ Pandan, Winona A. \\ The Colombo Plan, Sri Lanka (winona.pandan@ colomboplan.org)
}

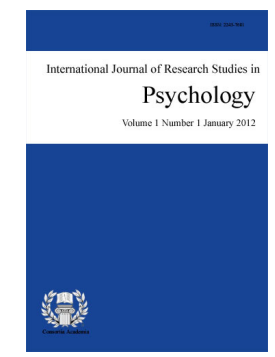

ISSN: $2243-7681$ Online ISSN: 2243-769X

OPEN ACCESS

\section{Abstract}

Substance abuse is a social problem that pervades many societies worldwide. Although a lot of research has been done on this topic, little is known about the family dynamics of the drug addicts which could provide vital inputs to the intervention programs conducted in treatment centers in the Philippines. This research attempts to describe and analyze the family dynamics in addiction through qualitative research approach. Ten (10) male drug addicts confined in a rehabilitation center with their two family members were involved in the study. In-depth interviews generated rich narratives which were later subjected to content analysis. The study revealed that the drug addicts were mostly the middle child in their families, and had good relationships with their parents. Most of them are already "fathers". Upon being addicted to drugs, they were perceived negatively by their family members and it was their siblings and spouses who took courage to report them and send them to the rehabilitation center. The drug addicts and their families had relationship and communication patterns that can be described as both positive and negative. Positive patterns focused on openness and problem receptivity. While negative patterns focused on upholding the family's reputation and denying the presence of the drug problem; parents as enablers; fault finding; removal of support groups; denial and avoidance of significant other; and restrained relationships. Coping patterns revolved around those that enhance productive behaviors and change and those that do not. Positive and healthier coping patterns include taking an active role in solving the problem; engineering their social environment; enriching their spirituality; being provided with more support by family members; being aware of the existence of the problem and do something about it; asking for forgiveness; and being provided with a second chance. However, counterproductive coping styles include keeping the family secret; selecting problems that should be solved; hurting oneself or others; and withdrawing from the problem. The importance of family involvement in the treatment process is highlighted in the study.

Keywords: drug addiction; family dynamics; communication pattern; coping; family counseling 


\section{Examining the family dynamics in addiction: Inputs for treatment intervention in the Philippine setting}

\section{Introduction}

Drug addiction is a complex psychosocial problem that impacts not only the drug user/abuser but also the family as a whole. It is oftentimes referred to as a family disease because of its serious effects on the members and the functions of the family. Velleman and Templeton (2007) conservatively assumed that in every substance abuser at least two of their close family member would be affected. Indeed, families living with addiction often experiences problems associated with the drug use/abuse. They are the ones who carry the burden of their relative's addiction to drugs and its effects. It brings pain and disruption to their lives as they get trapped in the spinning cycle of addiction.

Family members may engage in roles and enabling behaviors that may maintain and/or support the progression of addiction. Parents commonly feel a sense of guilt and responsibility for what had happened to their son or daughter. Similarly, the spouses and significant others often feel the same way too. They go through the pattern of denial, helplessness and the need to take control. Siblings, on the other hand, may also appear engaged or withdrawn, depending on the quality of their relationship with the substance-abusing individual. Interactions and communication patterns between and among the members of the family become negative and unhealthy as the addiction progresses. In most cases, substance use becomes an open secret within the family. In the end, trying to live with the addiction becomes the normal routine among the family members and the ensuing problems result to a deeply disturbed family structures and dynamics (Barnard, 2005).

The underlying feeling of shame because of the stigma and the guilt attached to it made it impossible to openly discuss the problem even within their own family members. Although the family plays a major role in the successful drug treatment and recovery, it is not enough that they just remain to play a supportive role. They, too, become enmeshed in the cycle of addiction, thus they also need an intervention program that will assist them not only to develop an understanding of the nature and progression of the problem of drug abuse, awareness on the family processes and dynamics that emerged and how it influenced their roles and functioning but more importantly, it will provide them with skills to cope and manage their own recovery.

The purpose of this study was to find out the family dynamics of drug addicts. It tried to explore how addiction influences the addict and the family members to bring about insights on their experiences with the end result of offering vital inputs in the treatment and rehabilitation process of addicts in the Philippine setting. As the Philippine president (2016-2022) declares an all-out war against drug use, this study provided a crucial glimpse of the role of the family in the effort on treatment and rehabilitation of Filipino drug addicts. The focus of this study was on the family dynamics of drug addicts. Family dynamics as used in the study covers the following: 1) structure of the family of the addicts; 2) communication patterns within the family; and 3) how the family copes with the addiction. Based on the family dynamics, the study was able to crystallize a framework that depicted how the family dynamics was affected by the addiction prior to the commitment of the addict to a treatment and rehabilitation facility.

\section{Review of Related Literature}

\subsection{Defining the family}

Various groups and social institutions also define the family. According to Ward and Belanger (2011), there are two underlying differences in the way people regard families: the nuclear family and the extended family. 
The nuclear family is usually regarded as a married couple and their children. Nuclear families come in two forms: families of origin or orientation are those born we are born into and raised in; families of procreation re those we from through marriage or cohabitation and in which we raise our children. The second concept is the extended family, which encompasses the nuclear family and all other relatives. Some people include more distantly related cousins, for example, than others. In both nuclear and extended families, genetic and "blood" relationships are important, although most people recognize other types of relationships, such as marriage or adoption.

In recent years, family social scientists have come to view the family as a system. The systems approach to family looks at how the family is connected with society and at how individual members interact. A system contains a set of interrelated and interacting parts. Like all systems, anything that affects one part of the family will affect all parts (Montgomery \& Fewer, 1988 as cited in Ward \& Belanger, 2011). When viewed as a system, two central dimensions define the family: its structure and its tasks. Structure includes both the family's composition and its organization. Composition refers to the family's membership, or simply, the persons who make up the family. The family's structural organization refers to the unique set of rules governing the patterns of interaction found within the extended family system. Tasks refer primarily to the "business" of the family_its common and essential responsibilities. All families have tasks that they fulfill for society and family members alike.

\subsection{Family and Drug Use}

A growing body of literature suggests that substance abuse has distinct effects on different family structures. SAMSHA Treatment Intervention Protocols (1993) describes several characteristic patterns of interaction, one or more of which are likely to be present in a family that includes parents or children abusing alcohol or illicit drugs:

Negativism - Any communication that occurs among family members is negative, taking the form of complaints, criticism, and other expressions of displeasure.

Parental inconsistency - Rule setting is erratic, enforcement is inconsistent, and family structure is inadequate. Children are confused because they cannot figure out the boundaries of right and wrong.

Parental denial - Despite obvious warning signs, the parental stance is: (1) "What drug/alcohol problem? We don't see any drug problem!" or (2) after authorities intervene: "You are wrong! My child does not have a drug problem!"

Miscarried expression of anger - Children or parents who resent their emotionally deprived home and are afraid to express their outrage use drug abuse as one way to manage their repressed anger;

Self-medication - Either a parent or child will use drugs or alcohol to cope with intolerable thoughts or feelings, such as severe anxiety or depression;

Unrealistic parental expectations - If parental expectations are unrealistic, children can excuse themselves from all future expectations by saying, in essence, "You can't expect anything of me - I'm just a pothead/speed freak/junkie." Alternatively, they may work obsessively to overachieve, all the while feeling that no matter what they do is never good enough.

Barnard (2007) in her two-year research project on drugs in the family was able to document the journey recounted by the participants through three stages: discovery of the drug problem; attempts to manage and live with it; and, the final expulsion of the problem drug-using relative from close contact with the family. She described that at the beginning, the development of a drug problem in a close family member was often an insidious process marked by small but significant changes in manner, behavior and appearance (Usher, Jackson, \& O'Biren, 2005 as cited in Barnard, 2007). She wrote that five of the families interviewed did not realize for up 
to two years that drugs were behind these behavior changes although in nearly all the cases the drug problem had developed once their child had left the family home and was living independently. Becoming defiant, withdrawn and secretive, easily irritated and agitated, having funny eyes and slurred speech, disappearing without notice, missing money and goods, were all cues that cumulatively led to the suspicion that drugs were at the heart of the behavior changes observed.

\subsection{Families' Coping Strategies}

In a review of literature, Macdonald (2002) enumerated the ways that families respond to drug use: 1) Denial - The family denies that there is a problem. This can be a viable response in avoiding confrontation, although its effectiveness is usually short-term. Long term denial tends to store up issues rather than addressing them which can result in greater upset and turbulence; 2) Self-blame- The family takes responsibility for the situation; for example, the parents blaming themselves for child's drug use. There is a danger that this is reinforced if the family is regarded as part of the problem rather than the solution. This can be a substantial barrier to accessing support; 3) Blame- The family assign responsibility for the situation to others: for example, on the drug user's peer group, social workers or drug workers for not 'solving' the problem. This can result in animosity and anger towards agencies. This makes it difficult for supportive relationships to be developed; 4) Tough love - Families can respond by creating distance between themselves and the drug user; either physically or emotionally. This can range from ensuring that the family does not give in to pressure from the drug user, to extremes such as removing the drug user from the family home. This can demand a substantial amount of detachment from feelings that the family may have towards the drug user.

\subsection{Family Communication Patterns}

Wegscheider (1989) proposed two patterns of communication within the family. First is the socio-oriented family communication structure where children are directed to obey elders and aspire for a harmonious relationship with others. This pattern of communication raises children in an environment where they are taught to avoid controversy and they do not participate in the decision-making processes at home. Also, the children are expected not to argue with adults and to give in on topics instead of risking offending others. The second pattern is the concept-oriented communication where the family was taught that the problem itself is the focus when dealing with a conflict instead of the people who create it. They are taught to weigh all of the alternatives before making a decision and then they may argue the problem and use evidence when they believe they are correct. The children are also taught not to be afraid of arguing or antagonizing others.

\subsection{Intervention Programs for Families with Drug Addiction Problem in the Philippines}

Mercado (2000) stressed that within the field of substance abuse treatment and prevention, family counseling is an important component of an effective intervention program because substance abuse is considered a family disorder. The basic premise of the family system theory (Mercado, 2000) is that familial homeostasis is based on the differentiation of self/fusion from the family. It comprises of the following basic tenets:

Differentiation of the self/fusion - This pertains to the association between the intellect and goal-directed activity and emotion or emotional oriented activities. A differentiated individual is flexible, thoughtful, and autonomous. Fusion is the opposite, in which the individual is ruled by emotion, is rigid and prone to dysfunctional behavior in stressful situation.

Triangles - These pertain to forms of fusion in the family used to maintain homeostasis during crises or between two members experiencing anxiety. It involves a third party to alleviate emotional stress and tension to regain family stability.

Nuclear family's emotional system - This tenet is related to the family members' achievement of emotional 
Examining the family dynamics in addiction: Inputs for treatment intervention in the Philippine setting

maturity is considered dependent on their parents' emotional maturity. Emotional maturity is associated, on the other hand, with the levels of differentiation and fusion.

Family projection process - This means that parents have the tendency to project their level of differentiation onto the most vulnerable child. The intensity of projection process is determined by the degree of undifferentiation of the parents as well as the amount of stress and anxiety the family experiences.

Multigenerational transmission process - It is the transmission of functioning from one generation to another. The levels of differentiation and fusion are transmitted not only through the immediate family but also from previous generations.

Sibling positions - It is an important factor in family responsibilities and roles and usually the older children are more adult-like in their behavior, and parental expectations for them to succeed, is higher. Middle children are expected to be more social while the younger siblings are more rebellious and usually unconstrained by family rules.

There is indeed a dearth in the study on drug addiction as a family disorder in the Philippine setting and this study attempted to enrich the current literature as much as it provided practical implications to practice of the counseling profession. Inputs for the education sector to integrate the concept of "family" in the treatment of substance use disorder were also offered.

\section{Methods}

The study used the in-depth interview method of research. As one of the most common qualitative methods, it is designed to elicit a vivid picture of the participant's perspective on the research topic. Through this method, the researcher poses questions in a neutral manner, listens attentively to the participants' responses, and asks follow-up questions and probes based on those responses.

Ten (10) drug addicts and their respective families were purposively chosen as participants of the study. These drug addicts were called residents at a Treatment and Rehabilitation Center in the Philippines' National Capital Region as they were undergoing treatment and rehabilitation at the same center. This Center caters only to male drug addicts. The criteria for choosing the research participants are as follows:

$>\quad$ Had been confined in the center for at least one month, at the time of the interview;

Has immediate family members who visit him at the center during visiting days;

$>\quad$ Has signified intention to share his life stories for research purposes only; and

$>\quad$ At least two of his family members also signified intention to be interviewed and be part of this research.

There were two sets of interview guide developed and validated in the study. One is for the drug addict-resident and the other one for the family. The content of both explored the family dynamics before and after a member of the family became involved with drugs. The program director of the treatment center helped the researchers identify participants and broach the idea of the research to them. Although the subjects were pre-selected, the participants were given the choice to join or not to join. Upon their agreement, the researcher scheduled the meeting. The researcher oriented the prospective participants about the background and the procedure of the study. An informed consent form was discussed and signed by the respondents. Information sheets accomplished by the participants at the rehabilitation center were reviewed at the time they were admitted and the results of the psychological assessment done by the visiting psychologist of the center so as to gather pertinent demographics as well as background information surrounding their addiction to drugs.

All interview sessions were held in the Director's office in the facility for privacy. The drug addict-resident 
Abulon, E. L., \& Pandan, W. A.

of the center was interviewed during the first session. The family members were interviewed during their visiting days at the center. Approximately two hours of a single interview session was devoted to each of the respondents (the drug addict-resident, a parent or spouse and a sibling or a child).

The interview session's proceedings were transcribed in verbatim format to cull relevant information about the family dynamics. Three sets of the transcripts of the interview were produced for analysis for three independent judges who are also addiction counselors and have done qualitative studies in the field of counseling psychology to establish inter-rater reliability. They worked independently to identify and code statements from the transcripts which are considered significant to the research questions. Significant statements per transcript were consolidated which became the units of analysis. Grouping of significant statements or the units into themes across the transcripts, based on similarities and differences was done through the use of Qualizer Qualitative Data Analysis Software, a content analysis program that categorizes responses with regard frequency and salience. Lastly, themes were organized into tables for presentation and interpretation.

\section{Results and Discussion}

\subsection{Family Structure: Roles, Perceptions and Responsibilities}

In examining the family structure, Table 1 presents the pertinent information of the cases to provide a picture of how their drug problem was addressed at the beginning. Ten (10) male drug users were interviewed. It is very evident that most drug-users (8) come from large families who with their parents being able to financially respond to their family needs. Most of their parents are earning well for a living, most of the drug users and their sibling had been sent to formal school up until college. Although many of them have already been raising their own families, their experiences of drug-use have started when they were actually younger. Hence, the need for seeking for professional help was mostly initiated by their parents or by their siblings. Although most drug users described their relationships with their parents, especially with their mothers, as meaningful, their relationship with their siblings seemed to be unstable. They seemed to have conflicts with one another that are rooted from their early childhood days. Consequently, these conflicts have been elevated to undesirable behaviors such as externalization of aggression, verbal assault, and dishonest behavior. These behaviors, especially the physical aggression, have extended to some of their present family relationships. There were romantic partners who have reported physical abuses. Despite of these, their siblings have showed support in struggle of the drug-user to overcome their dependency to drugs.

\section{Table 1}

Family Structure of the 10 Cases

\begin{tabular}{|c|c|c|c|c|c|}
\hline Cases & $\begin{array}{l}\text { Number of Members in } \\
\text { Family of Origin }\end{array}$ & Birth Order & $\begin{array}{c}\text { Number of } \\
\text { Members in Family } \\
\text { of Procreation }\end{array}$ & $\begin{array}{c}\text { Family } \\
\text { Members who } \\
\text { sought help for } \\
\text { the drug addict }\end{array}$ & $\begin{array}{l}\text { Family Members' } \\
\text { Description of the } \\
\text { drug addict }\end{array}$ \\
\hline Case 1: F & $\begin{array}{l}8 \\
\text { Parents were both } \\
\text { professionals (retired } \\
\text { principals) }\end{array}$ & Middle Child & 5Children & Brother & $\begin{array}{l}\text { Aloof } \\
\text { Secretive }\end{array}$ \\
\hline Case 2: Ry & $\begin{array}{l}10 \\
\text { Father (deceased) was a } \\
\text { sales agent } \\
\text { Mother is a housewife }\end{array}$ & Youngest & None & Older siblings & $\begin{array}{l}\text { Not interested to } \\
\text { study } \\
\text { Lazy }\end{array}$ \\
\hline Case 3: $\mathrm{H}$ & $\begin{array}{l}6 \\
\text { Father (deceased) was a } \\
\text { lawyer and an alcoholic } \\
\text { Mother is a retired } \\
\text { government employee }\end{array}$ & $\begin{array}{l}\text { Middle child } \\
\text { (only son) }\end{array}$ & None & Elder sister & Aggressive \\
\hline
\end{tabular}


Examining the family dynamics in addiction: Inputs for treatment intervention in the Philippine setting

\begin{tabular}{|c|c|c|c|c|c|}
\hline Cases & $\begin{array}{l}\text { Number of Members in } \\
\text { Family of Origin }\end{array}$ & Birth Order & $\begin{array}{c}\text { Number of } \\
\text { Members in Family } \\
\text { of Procreation }\end{array}$ & $\begin{array}{c}\text { Family } \\
\text { Members who } \\
\text { sought help for } \\
\text { the drug addict } \\
\end{array}$ & $\begin{array}{c}\text { Family Members' } \\
\text { Description of the } \\
\text { drug addict }\end{array}$ \\
\hline Case 4: Rly & $\begin{array}{l}5 \\
\text { Father (deceased) was a } \\
\text { construction worker } \\
\text { Mother is a government } \\
\text { employee }\end{array}$ & Middle child & 3 children & Wife & Easily irritated \\
\hline Case 5: KL & $\begin{array}{l}5 \\
\text { Father is a power crane } \\
\text { operator } \\
\text { Mother is a housewife }\end{array}$ & Youngest & 3 children & Parents & Aloof \\
\hline Case 6: Rl & $\begin{array}{l}5 \\
\text { Father (deceased) } \\
\text { Mother works overseas }\end{array}$ & Eldest & 4 children & Daughter & $\begin{array}{l}\text { Aggressive } \\
\text { Threatened to kill } \\
\text { the family }\end{array}$ \\
\hline Case $7: \mathrm{K}$ & $\begin{array}{l}6 \\
\text { Father and mother are } \\
\text { working }\end{array}$ & Middle child & 3 children & Mother & $\begin{array}{l}\text { Easily irritated } \\
\text { Always angry }\end{array}$ \\
\hline Case 8: Rd & $\begin{array}{l}7 \\
\text { Father (deceased) } \\
\text { Mother works }\end{array}$ & Youngest & 3 children & Father & $\begin{array}{l}\text { Physically } \\
\text { abuses his wife }\end{array}$ \\
\hline Case 9: Gn & $\begin{array}{l}8 \\
\text { Parents own a business }\end{array}$ & Middle child & None & Brother & $\begin{array}{l}\text { Fights and } \\
\text { argues with wife }\end{array}$ \\
\hline Case 10: J & No data & No data & 3 children & Wife & $\begin{array}{l}\text { Steals from } \\
\text { parents and wife }\end{array}$ \\
\hline
\end{tabular}

In the literature, families were seen to have provided four important societal functions (Mercado, 2000): (1) it provides a source of intimate relationships, (2) it acts as a unit of economic cooperation and consumption, (3) it may produce and socialize children, and (4) it assigns social roles and status to individuals. The functions are imperative in ensuring that people who are a product of this institution to adjust and cope with the society's challenges. The structure of the drug user's family seem to highlight that the tendency to abuse drugs is prevalent across socio-economic statuses, number of family members, birth order, and whether a person has his own family or not. Likewise, drug use affects the family member's perception of the user and what would be highlighted are negative character traits.

\subsection{Communication pattern within the family}

The nature of communication and relationship between and among members of drug-users can be described as both warm and cold. It is warm in the sense that most members of the family have tried to express their concern and love towards the drug-user, especially during the time when the drug-users were on the height of drug dependency. It is cold, on the other hand, because of the inability to address the main problem at hand and the nature of actions made in trying to help drug-user. The intention to help the drug-user were a mix of personal and collective pride with regard how the society will respond to such situations and the concern and love for the person. These two perspectives came out evident among the themes from the drug-user themselves and the informants' account.

Confrontation atmosphere: Openness - This theme describes the nature of response that significant others made when they learned about the drug-related activities of the drug-user. It can be considered that this process can be characterized as a struggle among the family members, especially in accepting the drug-user's confession. They have showed varied emotional reaction such as anger, dismay, and disappointment. However, these reactions can be seen as rather a concern to the drug-user than rejecting them. Despite of these reactions, the 
family members were also able to hold on their temper and manage to make sense with what they learned. Specifically, they have tried to regulate their emotions and instead find possible solutions to the problem at hand such as seeking for medical help and changing one's environment. Serious conversations were also done with the hope to enlighten the drug-user and avoid from engaging further in drug-related activities.

Importance of the Family's Reputation - Since most families live in close relationship in the community they belong, it becomes a concern among them, especially parents, from limiting the information to spread among the members of the community. It is not only in the context of actually using drugs but as well as in the course of rehabilitation. Family members have particularly considered how others will think about them considering their status on life.

Enabling parents - In the narration of both the drug-users and their family members, there have been instances where parents showed high tolerance behavior towards the drug dependency. Tolerance is defined as being less discouraging in engaging in drug-related activities as well as providing explicit or implicit supports toward the use of drugs.

Ensuring that love is felt - This theme explains that parents appeared to show extra effort in making the drug-user feel their love. Parents to some extent become the provider to the needs to the drug-user in order to sustain their vices. This is especially evident when they already have knowledge about the drug-related activities of the drug-user. Aside from this, parents showed higher level of trust to the drug-user. They believe that they can make sound choices considering their age.

Receptivity of Family Members to the Problem - Upon learning that one of their family members has been using drugs, the family became an automatic social support. All family members who can provide help were involved in dealing with the problem at hand. In this context, family members tried to exhaust the means of solving the drug activities of the user by including those accidental individuals, like the peers, to avoid from influencing the drug-user from further encouraging.

Fault finding - In the experience of the family members and the drug-user, they have been consistently attributing changes in the behavior of the drug-user to the drugs. This is most especially evident in finding reason why drug-users have showed different dispositions in dealing with them. Noticeably, drug-users were found to become more irritable, aggressive, and less emotionally regulated. They find it appropriate to blame the drug also as the cause of the other problems that later on came out.

Removal of support group - Part of the themes that came out was the identification of the cause that the drug-user from engaging in drug-related activities. It is prevalent that drug-users and their family consistently identified that a loss of a family member triggered either the beginning of or re-engaging with drug use. Specifically, they found the use of drugs as an effective way of coping in their sadness and longing. This experiences, however, did not only led to more drug-related activities but some drug users found it was as an enlightening experience that made them decide to finally enter in a rehabilitation facility. The loss of a loved one motivated them to fix the life and be the best person possible.

Denial and avoidance of significant others - Since the use of drugs is an undesirable outcome, the drug-user tried hard to keep this information from family members, especially those who are in charge in the financial aspect of the family. Largely, drug-users were using some of their money in buying the drugs that are intended to other household concerns

Restrained relationship - During and after drug-use, it has been observed that there was a significant change in the way they have related with one another. They appeared to be less communicating with one another and that have become emotionally detached especially to the member of the family to become engaged to drug use. This became evident in the type of emotional reactions that other family members have narrated. Their engagement to drugs also motivated them to avoid further interaction to other family members such as their 
children, wife, siblings, and parents.

\section{Table 2}

Underlying themes on the communication patterns within the Family

\begin{tabular}{|c|c|c|c|c|}
\hline Themes & Definition & $\begin{array}{c}\text { Cases where themes } \\
\text { are evident }\end{array}$ & Point of View & Frequency \\
\hline $\begin{array}{l}\text { Confrontation } \\
\text { Atmosphere: } \\
\text { Openness }\end{array}$ & $\begin{array}{l}\text { The drug users and their family members } \\
\text { focused on the type of emotions that } \\
\text { prevailed during the time truth came out } \\
\text { about their drug use. This was also the } \\
\text { emerging theme when the drug users } \\
\text { were being told that they will be placed } \\
\text { in a rehabilitation facility. }\end{array}$ & $\begin{array}{l}\text { Case } 1 \\
\text { Case } 2 \\
\text { Case } 5\end{array}$ & $\begin{array}{l}\text { Drug user and } \\
\text { family members }\end{array}$ & 5 \\
\hline $\begin{array}{l}\text { Importance of the } \\
\text { Family's } \\
\text { Reputation }\end{array}$ & $\begin{array}{l}\text { The need of the parents to keep the } \\
\text { community from knowing that their son } \\
\text { is using drugs }\end{array}$ & Case 1 & $\begin{array}{l}\text { Family Members } \\
\text { (Mother) }\end{array}$ & 3 \\
\hline $\begin{array}{l}\text { The Enabling } \\
\text { Parent }\end{array}$ & $\begin{array}{l}\text { Family members' description of how } \\
\text { "open" their communication is. They are } \\
\text { aware of the drug use and the user } \\
\text { admitted doing drugs in front of his } \\
\text { parents. The parent tolerates the use of } \\
\text { drugs and views it as showing love to his } \\
\text { or her children. }\end{array}$ & Case 2 & $\begin{array}{l}\text { Drug user and } \\
\text { family members }\end{array}$ & 3 \\
\hline $\begin{array}{l}\text { Ensuring that love } \\
\text { is felt }\end{array}$ & $\begin{array}{l}\text { Parents wanting to maintain a good } \\
\text { family and believes that by allowing their } \\
\text { sons do their vice they communicating } \\
\text { love }\end{array}$ & Case 2 & Family members & 2 \\
\hline $\begin{array}{l}\text { Receptivity of } \\
\text { Family Members to } \\
\text { the Problem }\end{array}$ & $\begin{array}{l}\text { The drug user's perception that his family } \\
\text { was willing to help him with his drug } \\
\text { problem. }\end{array}$ & Case 3 & Drug user & 2 \\
\hline Fault finding & $\begin{array}{l}\text { The family members' tendency to } \\
\text { attribute the drug problem to the } \\
\text { decisions made by the drug user and how } \\
\text { the parents allowed the user to go on with } \\
\text { his vice. This also includes accusing the } \\
\text { user of the }\end{array}$ & $\begin{array}{l}\text { Case } 3 \\
\text { Case } 8\end{array}$ & $\begin{array}{l}\text { Family member } \\
\text { (sibling) }\end{array}$ & 3 \\
\hline $\begin{array}{l}\text { Removal of } \\
\text { Support Groups }\end{array}$ & $\begin{array}{l}\text { Changes occurring to the drug user that } \\
\text { resulted in abusing drugs. A death of a } \\
\text { family member was often mentioned as a } \\
\text { primary cause in strained relationships } \\
\text { between drug user and his family. }\end{array}$ & $\begin{array}{l}\text { Case } 3 \\
\text { Case } 4 \\
\text { Case } 5\end{array}$ & Drug User & 10 \\
\hline $\begin{array}{l}\text { Denial and } \\
\text { avoidance of } \\
\text { significant others }\end{array}$ & $\begin{array}{l}\text { Family members reported not being } \\
\text { prepared for the truth of drug use, thus } \\
\text { would deny the presence of the problem } \\
\text { and avoid confrontation with the user } \\
\text { about his drug problems. }\end{array}$ & $\begin{array}{l}\text { Case } 4 \\
\text { Case } 6 \\
\text { Case } 9\end{array}$ & $\begin{array}{l}\text { Wife } \\
\text { Daughter } \\
\text { Mother }\end{array}$ & 4 \\
\hline $\begin{array}{l}\text { Restrained } \\
\text { relationship }\end{array}$ & $\begin{array}{l}\text { Drug user and family member reported } \\
\text { changing relationships between the } \\
\text { family and the users. The users reported } \\
\text { that his family became distant after } \\
\text { discovering his drug problems. }\end{array}$ & $\begin{array}{l}\text { Case } 5 \\
\text { Case } 6 \\
\text { Case } 7 \\
\text { Case } 8 \\
\text { Case } 9 \\
\text { Case } 10\end{array}$ & $\begin{array}{l}\text { Drug user and } \\
\text { family members }\end{array}$ & 6 \\
\hline
\end{tabular}

\subsection{Family coping patterns}

There were 11 themes emerging from the drug users' and family members' accounts, which could be inferred to as both productive and counter-productive. The themes were focused on how the drug users saw solutions to their addiction problems and their family members' ways in handling the problem. Excerpts from the interviews were likewise presented. Table 3 defines the themes, cases where themes were evident, the themes' point of views and the frequency to which the themes were prevalent.

Taking an active role in solving the problem - In the process of using drugs, the drug-user seemed to have 
realization on the extent by which family members have been affected by those drug-related activities. Because of these, drug-users have also expressed interest towards changing their state of activities by initially refusing from further using the drugs. Going through into their accounts, drug-users have found themselves responsible for whatever relational damage that their wrong doings have brought to their loved ones.

Engineering the social environment - As the drug-user realizes that continuous engagement with drug-related activities will worsen his condition and his relationship with his family members, he rectifies it by changing the kinds of people he interacts with. More specifically, those who have great influence on him in drug use were avoided. These strategies were seen to be an effective approach in order to divert one's attention to other things and not be persuaded to either progress in the use or trying it again after undergoing treatment and rehabilitation. Some drug-user also tried to establish new relationships, like meeting new acquaintances and friends in order to start anew.

Enriching one's spirituality - The use of drug was considered not only a challenge to one's family but as well as to one's relationship with the supernatural being. It is a challenge of how strong one's faith that the crisis will be overcome. Drug-users have become more prayerful than before.

Keeping the family's secret - Instead of sharing the crisis being experienced, it is rather kept among the family. It is thought to be a better approach in order to avoid from being misjudged by other people. This also is a form of escape from revealing so much information about the conflicts between and among family members that some drug-user identified to contribute significantly in their drug-related activities.

Choosing to solve problems selectively - It is evident the some drug-users have realized the cost of using drugs in their family relation as well as in their health condition. Hence, they approach it by avoiding the use of drugs. However, they do not intend to full withdraw from drug-related activities as they also see this as their means of living. With this, they are considered to be partial in approaching or solving the problems by only avoiding the use but not the drug pushing activities.

Gaining support from family members - One of the major support groups that drug-users identified in the whole drug-related experience, from the admission of the crisis until undergoing rehabilitation, is their family member. They served as an inspiration to them, especially during the time they were at the rehabilitation centers. More importantly, the emotional support that their family members provide made them stronger. This also contributed in their intention to finish the rehabilitation program. Moreover, their family members provided assistance in planning their lives after the rehabilitation.

Realizing the need to be rehabilitated - This is considered a major turning point to some drug-users. Although some have admitted to difficulty in choosing to undergo rehabilitation, they, however thought that their condition needed professional assistance already. They believed that they will be able to become the better person that they can be for their family members if they undergo rehabilitation.

Asking for forgiveness from family members - In the course of admission of the drug-user activities, they become emotional as they were also recognizing their mistakes in that whole situation. This is also accompanied by a guilt feeling that has caused conflict among family members and has challenged the relationship of the family members, in general. This realization prompted them from asking for forgiveness since they feel that they have hurt, offended, and disrespected their family members. More importantly, it is not only the drug-user who recognized their mistakes but also other members of the family. They acknowledge their shortcomings as parents or wife and may have contributed in the drug-user's activities.

Being provided with second chances by the family - As the drug-used found themselves improving as result of their strategy, they also felt from their families the opportunity to prove their self again. Their families have showed openness to the drug-user that they can still change and take a better track in life. This is especially evident to those who have undergone rehabilitation. The family members had high hopes that rehabilitation will 
Examining the family dynamics in addiction: Inputs for treatment intervention in the Philippine setting

not only stop them from engaging in drug-related activities but also taking life as serious matters.

Displaying counterproductive behaviors - The desire to change was not consistent among all the drug-users. There are those who have instead developed a counterproductive behavior such as stealing or hurting a family member. These are considered counterproductive since they rather harm the relationship.

Displaying withdrawal-related behaviors - Some family members tried to divert all their attention from addressing the problems that they are facing. Instead of taking an appropriate action with the drug activities, they engage into family activities that suspended, denied, or ignored the existence of the problem. These activities include, but not limited, limiting the interaction with the user and creating an activity for the family members that will make them preoccupied.

Table 3

Underlying themes on how the family copes with addiction

\begin{tabular}{|c|c|c|c|c|}
\hline Themes & Definition & $\begin{array}{l}\text { Cases where } \\
\text { themes were } \\
\text { evident }\end{array}$ & $\begin{array}{l}\text { Point of } \\
\text { View }\end{array}$ & Frequency \\
\hline $\begin{array}{l}\text { Taking an active role in } \\
\text { solving the problem }\end{array}$ & $\begin{array}{l}\text { The drug user's decision to change his or } \\
\text { her life by refusing to abuse drugs }\end{array}$ & $\begin{array}{l}\text { Case } 1 \\
\text { Case } 8 \\
\text { Case } 10\end{array}$ & Drug User & 3 \\
\hline $\begin{array}{l}\text { Engineering the social } \\
\text { environment }\end{array}$ & $\begin{array}{l}\text { The drug user's decision to choose the } \\
\text { people he will interact with and the active } \\
\text { avoidance of peers who influenced him to } \\
\text { use drugs }\end{array}$ & $\begin{array}{l}\text { Case } 1 \\
\text { Case } 10\end{array}$ & Drug User & 2 \\
\hline $\begin{array}{l}\text { Enriching one's } \\
\text { spirituality }\end{array}$ & $\begin{array}{l}\text { The drug user's decision to become closer } \\
\text { with God }\end{array}$ & $\begin{array}{l}\text { Case } 1 \\
\text { Case } 2 \\
\text { Case } 10\end{array}$ & $\begin{array}{l}\text { Drug User } \\
\text { and Family } \\
\text { Members }\end{array}$ & 5 \\
\hline $\begin{array}{l}\text { Keeping the family's } \\
\text { secret }\end{array}$ & $\begin{array}{l}\text { Family members' choice to keep the } \\
\text { condition from the knowledge of the } \\
\text { relatives and the community because it } \\
\text { will bring shame to the family. }\end{array}$ & Case 1 & Mother & 2 \\
\hline $\begin{array}{l}\text { Choosing to solve } \\
\text { problems selectively }\end{array}$ & $\begin{array}{l}\text { The drug user admitted that he or she will } \\
\text { stop drug use but not in selling it }\end{array}$ & Case 2 & Drug User & 2 \\
\hline $\begin{array}{l}\text { Gaining support from } \\
\text { family members }\end{array}$ & $\begin{array}{l}\text { The drug user's perceived support coming } \\
\text { from his family members to help him } \\
\text { recover }\end{array}$ & $\begin{array}{l}\text { Case } 3 \\
\text { Case } 4 \\
\text { Case } 6\end{array}$ & $\begin{array}{l}\text { Drug User } \\
\text { Wife } \\
\text { Family } \\
\text { members }\end{array}$ & $\begin{array}{l}3 \\
2 \\
2\end{array}$ \\
\hline $\begin{array}{l}\text { Realizing the need to be } \\
\text { rehabilitated }\end{array}$ & $\begin{array}{l}\text { The drug user's realization that he needs } \\
\text { to change for his family specifically his } \\
\text { children. The moment he sees that he is } \\
\text { not treated the way he used to be treated } \\
\text { by his family (e.g. with coldness and } \\
\text { anxiety) }\end{array}$ & $\begin{array}{l}\text { Case } 4 \\
\text { Case } 5\end{array}$ & Drug User & 5 \\
\hline $\begin{array}{l}\text { Asking for forgiveness } \\
\text { from family members }\end{array}$ & $\begin{array}{l}\text { Drug user's active role in enacting } \\
\text { change. The user believes that the first } \\
\text { step to recovery is to admit his mistakes } \\
\text { to the people he loves. }\end{array}$ & Case 5 & Drug User & 3 \\
\hline $\begin{array}{l}\text { Being provided with } \\
\text { second chances by the } \\
\text { family }\end{array}$ & $\begin{array}{l}\text { This focuses on the family members' } \\
\text { efforts to provide opportunities to the } \\
\text { drug user e.g. being given the chance to } \\
\text { study again, have a new source of income }\end{array}$ & Case 5 & $\begin{array}{l}\text { Family } \\
\text { members }\end{array}$ & 2 \\
\hline $\begin{array}{l}\text { Displaying } \\
\text { counterproductive } \\
\text { behaviors }\end{array}$ & $\begin{array}{l}\text { The drug user's tendency to display } \\
\text { inappropriate behaviors that may hurt or } \\
\text { affect his significant others (e.g. stealing, } \\
\text { beating others, attempting suicide) }\end{array}$ & $\begin{array}{l}\text { Case } 5 \\
\text { Case } 7\end{array}$ & $\begin{array}{l}\text { Drug user } \\
\text { and Family } \\
\text { members }\end{array}$ & 2 \\
\hline $\begin{array}{l}\text { Displaying } \\
\text { withdrawal-related } \\
\text { behaviors }\end{array}$ & $\begin{array}{l}\text { The family member's tendency to divert } \\
\text { concerns about addressing the drug } \\
\text { problems of the user by engaging in } \\
\text { activities that will limit his/her interaction } \\
\text { with the user (e.g. shopping spree, moving } \\
\text { out of the house, minimizing interactions } \\
\text { with the user). }\end{array}$ & $\begin{array}{l}\text { Case } 8 \\
\text { Case } 9\end{array}$ & & 2 \\
\hline
\end{tabular}


Again, the family system theory as presented by Mercado (2000) supported the above-cited discussion. A particular sibling in the lives of the ten cases portrayed the role of being the "hero" in the family. For most of them, the mother served as an enabler of her child's drug addiction. In order to pacify their child's tantrums especially during drug-craving moments, they provided money and other valuables that the drug-dependent child used to purchase drugs. They all said they pitied their sons that led them to give in to their wishes--a fact which their other children viewed as overindulgence and thus deeply resented. These findings that are common across the three cases under study supported the findings of Mercado (2000) as she emphasized the survival roles of the members in order to cope with the drug addiction problem in the family. Particular role that surfaced is the role of being the "enabler" of the addiction that has been portrayed by the mothers of almost all the cases.

All the families interviewed for this study disclosed that initially they tried to cope with the situation of having a drug addict family member by becoming permissive and turning a blind eye to the problem. They believed that by doing so, they would later on be successful in expressing their love to the drug-dependent individual, in the process convincing him that there is no need to take drugs. These particular findings echoed what Orford with his colleagues presented in 2010 when they carried out a number of studies of the coping styles adopted by family members of alcohol and drug dependents. The families being so permissive pushed them to tolerate the drug taking activities. Tolerance, according to Orford et al. (2010) reflects the extent in which the members of the family just accept the drug use. Accepting the member's drinking/drug use as it is, tacitly approving drinking/drug use by providing money, providing assistance to deal with drinking related problems or giving up other things to handle drinking related activities are all forms of tolerance.

\subsection{Towards a framework on family dynamics as affected by drug addiction}

Based on the discussed underlying commonalities that were culled from the qualitative data, the following linear framework was derived (see Figure 1). Throughout the ordeal of having a drug-dependent family member, the entire family faces the strain and anxiety of living with someone who tends to display deviant behaviors, such as violence/aggression, stealing, verbal abuse, and the like. Initially, the family copes by being permissive of the drug-taking acts, in the hope that this will somehow curb or lessen the drug addiction. Moreover, at this stage, the mother, who tends to feel guilt over her son's addiction, serves to enable the drug addiction by providing her son with the means towards the procurement of drugs. Finally, when the drug addiction has escalated to alarming levels, especially in the form of threat of increased physical violence, a sibling steps in to act as the crucial decision maker who convinces the rest of the family that the drug addict's confinement in a rehabilitation facility would serve him and the entire family best.

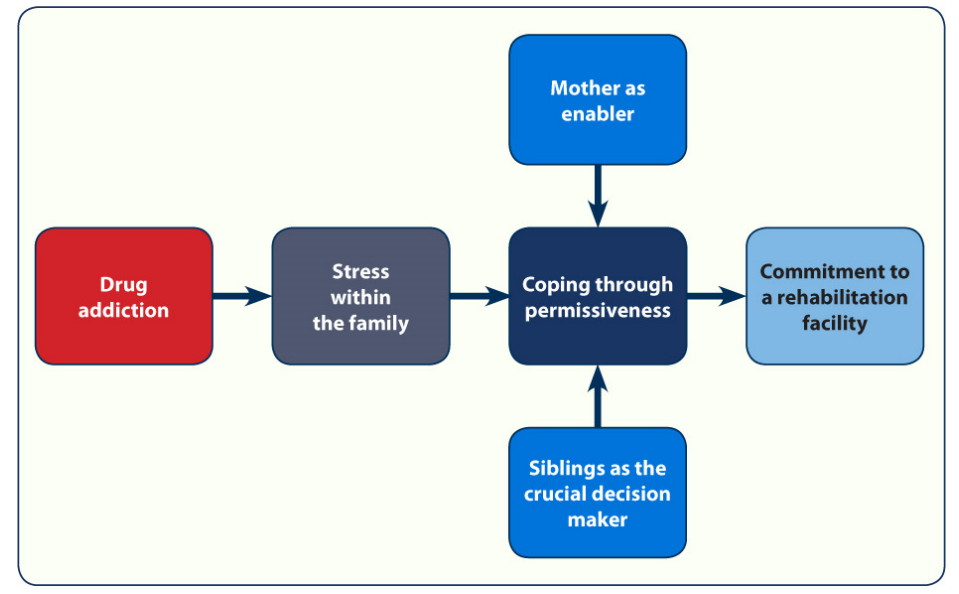

Figure 1. A Linear Framework of Family Dynamics as Affected by Drug Addiction 


\section{Conclusions and implications for practice}

Four points must be raised in view of the results presented. Firstly, although it may be second nature for Filipino families to initially try and employ leniency and permissiveness in response to a family member's drug-taking, one must realize that this is never the best strategy since early intervention is always the key to a speedy and successful recovery from any form of addiction. For all ten families interviewed, the belief that mollycoddling the drug addict member will make him change his ways merely served to protract the drug-taker's exposure to the illegal substance, thus pushing him further into the pit of addiction. In cases such as having a drug addict family member, proactive measures are always best.

Secondly, although it may be against a mother's nature, a drug addict's mother should avoid being an enabler of her son's drug-taking behaviors. As could be seen in the interviews, the mothers' lack of willpower to commit their sons to a rehabilitation facility and their overindulgence and provisioning their sons with the means to acquire drugs only served to strengthen their sons' addiction. One might say that mothers confronted with the same sorry predicament ought to utilize "tough love" which will lead their drug-dependent children towards faster recovery.

Third, the support coming from family members is an effective antidote to drug abuse. When the family communicates their support, forgiveness, and the opportunity to change to the drug users, veering away from the vice becomes concrete. The choice to face the difficulties and do something about it is not the sole decision of the drug user but a collective effort emanating from his significant others.

Lastly, the problem of drug addiction affects not only the drug-taker and his/her parents but the other children in the family as well. As such, they need to also have a voice in the situation. Based on the interviews, a sibling (usually older than the drug addict) served as the linchpin--that is, he/she was the crucial decision maker who convinced the rest of the family regarding the wisdom of confining the substance abuser to a rehabilitation facility. This highlights the need to enlist the help of family members in confronting the problem and for all to be united and supportive of each other during such a difficult time. Strong commitment from the immediate members of the family shall thereby be given emphasis in the treatment process so as to facilitate recovery.

\subsection{Recommendations}

The impact of addiction in the family dynamics shall be simultaneously addressed by the treatment and rehabilitation centers in the Philippines. Addressing this calls for the thorough assessment of the client's familial background. Particular attention should be given to the probability of permissiveness in the family regarding drug-taking activities, as well as the mother's or any family member's enabling character. Such initial information about the family of the client could be used as a basis for updating the facility's intervention programs regardless of their treatment approach. Conduct of regular family counseling is imperative in determining the level of social support they are willing to provide to the client, to enhance channels of communication among the members and to slowly realize each member's contribution in the recovery of the client leading to better coping with the stigma of addiction in the family. Alongside the family counseling, special sessions on psychoeducation for the families should be undertaken to foster deeper understanding of the nature of drug addiction and its exacerbating effects to the individual, to the family and to the society.

\section{References}

Barnard, M. T. (2007). Drugs in the family: The impact on parents and siblings. Retrieved from http://www.dldocs.stir.ac.uk/documents/1859353207.pdfwww.jrf.org.uk

Macdonald, D. V. (2002). Effective Interventions Unit (EIU) supporting families and careers of drug users: A Review. Retrieved from http://www.gov.scot/Resource/Doc/47007/0025628.pdf

Mercado, M. M. (2000). The invisible family: Counseling Asian American substance abusers and their families. The Family Journal, 8(3), 267-272. https://doi.org/10.1177/1066480700083008 
Abulon, E. L., \& Pandan, W. A.

Orford, J. M., Templeton, L. S., Copello, A. B., Velleman, R., \& Ibanga, A. M. (2010) Working with teams and organizations to help them involve family members. Drugs: Education, Prevention and Policy, 17(s1), 154-164. https://doi.org/10.3109/09687637.2010.514807

SAMHSA/CSAT. (1993). Treatment improvement protocols: Substance abuse and mental health services administration (US). Retrieved from http://www.ncbi.nlm.nih.gov/books/NBK82999/

Velleman, R.T., \& Templeton, L. R. (2003). Alcohol, drugs and the family: results from a long-running research program within the UK. European Addiction Research, 9(3), 103-112. https://doi.org/10.1159/000070978

Ward, M. G., \& Belanger, M. C. (2011). The family dynamic: A Canadian perspective. Vancouver: Nelson Education Publishing House.

Wegscheider, S.C. (1989). Another chance: Hope and health for the alcoholic family. New York: Science and Behavior Books. 